\title{
BALLISTOSPORE-FORMING YEASTS FOUND ON THE SURFACE OF THE JAPANESE RICE PLANT, ORYZA SATIVA L.
}

\author{
TAKASHI NAKASE AND MOTOFUMI SUZUKI \\ Japan Collection of Microorganisms, The Institute of Physical and \\ Chemical Research (RIKEN), Wako, Saitama 351-01, Japan
}

(Received December 10, 1985)

\begin{abstract}
Ninety-nine strains of ballistospore-forming yeasts were isolated from 43 samples of dead leaves and stems of the Japanese rice plant (Oryza sativa L.), and identified as belonging to the genera Bullera, Sporobolomyces, and Tilletiopsis. Thirty-one strains out of 55 of Bullera were assigned to $B$. alba (15 strains), B. crocea (13 strains), and B. piricola (3 strains). The remaining 24 strains of this genus were divided into 6 groups (species) which could not be assigned to any hitherto known species. Thirty-nine strains out of 41 of Sporobolomyces were assigned to $S$. roseus (35 strains) and $S$. shibatanus (4 strains). The remaining 2 strains of this genus were divided into 2 groups (species) which could not be assigned to any hitherto described species. Three strains of Tilletiopsis were assigned to $T$. lilacina. Of the 8 undescribed species, two were described respectively as the new species, $B$. oryzae and $S$. subbrunneus. Strains JCM 5281 and JCM 5278 respectively were designated as the types of the two species. Further study of the remaining 6 undescribed species is required before we determine their taxonomic position. The frequency of isolation of ballistosporeforming yeasts from Oryza sativa L. was $86 \%$. Sporobolomyces roseus was found in the highest frequency, $72 \%$, followed by Bullera sp. 1 $(35 \%), B$. crocea $(30 \%)$, and $B$. alba $(28 \%)$. The remaining species were found in relatively low frequencies below $9 \%$.
\end{abstract}

Ballistospore-forming yeasts are known as one of the most common yeasts. They are often found on the surface of various kinds of plants. Since the description of Torula shibatana and Pseudomonilia rubicundula by OKUnUKI (1), several investigations of the classification and distribution of these yeasts have been carried out in Japan (2-5). YAMASAKI and FUJII (2) described 5 new species of ballistospore-forming yeasts; 4 in Sporobolomyces and 1 in Bullera. However, three of these Sporobolomyces species were re-identified as known species (6) and the culture of Bullera (B. stramina) was lost. Sporobolomyces coralliformis (4) 
and Sporobolomyces japonicus (5) were also found in Japan and described as new species. However, both species are now considered to belong to known species (6). In 1969-1970, Yoshizawa and Komagata carried out an extensive study on yeasts living on the surface of various kinds of plants, and isolated 403 cultures of ballistospore-forming yeasts. In addition to 6 known species of Sporobolomyces and Bullera, they obtained 20 cultures which could not be assigned to any hitherto described species and assumed that some of them represented new species. Unfortunately, however, their study has not yet been published.

In the course of a survey on naturally occurring yeasts in Japan, we isolated ballistospore-forming yeasts living on the surface of the Japanese rice plant (Oryza sativa L.) and found that ballistospore-forming yeasts occur commonly on this plant. The identification of these isolates and the description of two new species are reported in this paper.

\section{MATERIALS AND METHODS}

Samples employed for the isolation of yeasts. Forty-three samples of dead leaves and stems of the Japanese rice plant, Oryza sativa L., were collected from rice fields in the Akabane and Tsutsumi districts in Chigasaki, Kanagawa Prefecture, during the period of Feb. 5 to Mar. 25, 1984. These rice fields are covered with water or in wet state all the year round and are called "Shitsu-den."

Isolation of yeasts. Yeasts were isolated by using the nature of ballistospores as reported by DerX (7). Small pieces of samples were stuck on the covers of YM agar (Difco Labs) plates and incubated for 3-5 days at $17^{\circ} \mathrm{C}$. The agar plates were replaced by new ones every day to recover slowly growing yeasts. After incubation for several days, colonies formed on the agar were investigated under a stereomicroscope at low magnification and colonies with different appearances were isolated.

Identification of yeasts. As soon as possible after purification by the conventional streaking technique, the ballistospore-forming ability of the yeasts was investigated. YM agar, corn meal agar (Difco Labs), and sterilized and dampened rice straw were employed for this purpose. Most of the morphological, physiological, and biochemical characteristics were investigated by the methods described in The Yeasts, a Taxonomic Study $(8,9)$. Vitamin requirements were tested by a method previously reported (10). Maximum growth temperature was determined in YM broth (Difco Labs) using metal block baths.

Chemotaxonomic investigation. Isolation of DNA, determination of DNA base composition, and extraction and determination of ubiquinone isoprenologues were accomplished by a method previously described (11).

\section{RESULTS AND DISCUSSION}

\section{Isolation and identification}

One hundred and seventy-five strains of yeasts were isolated from 43 samples 
of dead leaves and stems of rice plant. Of these, 94 strains were found to produce ballistospores and 5 were assigned to a certain ballistospore-forming species based on their taxonomic characteristics, even though they did not produce ballistospores. All strains were assigned to the genera of Bullera, Sporobolomyces, and Tilletiopsis (Table 1). Thirty-one strains out of 55 assigned to the genus Bullera were assigned to $B$. alba, B. crocea, or B. piricola. The remaining 24 strains of this genus were divided into 6 groups which were considered to represent various undescribed species. Thirty-nine strains out of 41 assigned to the genus Sporobolomyces were assigned to $S$. roseus and $S$. shibatanus. The remaining 2 strains of the genus were divided into 2 groups which were considered to represent undescribed species. Three strains of the genus Tilletiopsis were assigned to $T$. lilacina. Species identified in the present study are enumerated below:

1. Bullera alba (Hanna) Derx

Strains: NO-1, NO-70, NO-72, NO-77, NO-82, NO-98, NO-105, NO-109, NO-117, NO-141, NO-143, NO-148, NO-150, NO-170, NO-176.

The morphological, physiological, and biochemical characteristics of these 15 strains fit the standard descriptions of this species given by RoDRIGUES DE Miranda (12) and BARnEtT et al. (13), and those of the type strain of this species (CBS 501 = JCM 2954). The frequency of isolation of this species from rice plant was $28 \%$ (Table 1). This species is considered a common species living on the dead leaves of rice plants.

2. Bullera crocea Buhagiar

Strains: NO-7, NO-44, NO-62, NO-81, NO-89, NO-94, NO-110, NO-124,

Table 1. Ballistospore-forming yeasts found in Oryza sativa L.

\begin{tabular}{lcc}
\hline \multicolumn{1}{c}{ Species } & Number of isolates & $\begin{array}{c}\text { Frequency of isolation } \\
(\%)\end{array}$ \\
\hline Bullera & 55 & 67 \\
B. alba & 15 & 28 \\
B. crocea & 13 & 30 \\
B. piricola & 3 & 5 \\
B. oryzae sp. nov. & 1 & 2 \\
Bullera sp. 1 & 16 & 35 \\
Bullera sp. 2 & 3 & 7 \\
Bullera sp. 3 & 2 & 5 \\
Bullera sp. 4 & 1 & 2 \\
Bullera sp. 5 & 1 & 2 \\
Sporobolomyces & 41 & 79 \\
S. roseus & 35 & 72 \\
S. shibatanus & 4 & 9 \\
S. subbrunneus sp. nov. & 1 & 2 \\
Sporobolomyces sp. & 1 & 2 \\
Tilletiopsis & 3 & 7 \\
T. lilacina & 3 & 7 \\
Total & 99 & 86 \\
\hline
\end{tabular}


Table 2. Morphology of ballistospores and appearance of colonies of ballistospore-forming yeasts

isolated from Oryza sativa $\mathrm{L}$.

\begin{tabular}{|c|c|c|c|}
\hline Species & $\begin{array}{l}\text { No. of isolates } \\
\text { tested }\end{array}$ & Ballistospores & Colonies (YM agar, 1 month at $17^{\circ} \mathrm{C}$ ) \\
\hline B. alba & 15 & $\begin{array}{l}\text { globose to subglobose, } \\
\text { apiculate, }(2.5-8) \times(4-9) / / \mathrm{m}\end{array}$ & $\begin{array}{l}\text { melon to greyish orange, smooth or } \\
\text { slightly wrinkled, shining or dull, }\end{array}$ \\
\hline B. crocea & 13 & $\begin{array}{l}\text { turbinate, when produced. } \\
(3.5-8.5) \times(3.5-10 / ! \mathrm{m})\end{array}$ & deep orange, smooth, dull, semi-soft \\
\hline B. piricola & 3 & $\begin{array}{l}\text { ovoid to pyriform or reniform, } \\
(4.5-7) \times(7.5-13) / \mathrm{m}\end{array}$ & $\begin{array}{l}\text { light orange to greyish orange, smooth, } \\
\text { shining, soft }\end{array}$ \\
\hline B. oryzae & 1 & $\begin{array}{l}\text { globose, napiform, } \\
(4.5-8) / \mathrm{m} \text { in diam. }\end{array}$ & light yellow to apricot, smooth, dull, soft \\
\hline Bullera sp. 1 & 16 & $\begin{array}{l}\text { ovoid to pyriform or reniform, } \\
(4-8) \times(8-15) \mu \mathrm{m}\end{array}$ & pale orange to greyish orange, smooth, dull, soft \\
\hline Bullera sp. 2 & 3 & $\begin{array}{l}\text { chestnut-shaped with a hilum on the } \\
\text { deflected position, }(4-7) \times(5-9) / / \mathrm{m}\end{array}$ & $\begin{array}{l}\text { apricot to butter yellow, smooth or delicately } \\
\text { wrinkled, dull, semi-soft to butyrous }\end{array}$ \\
\hline Bullera sp. 3 & 2 & $\begin{array}{l}\text { globose, napiform, } \\
(3.5-6) ! \mathrm{m} \text { in diam. }\end{array}$ & $\begin{array}{l}\text { light orange to greyish orange, smooth, } \\
\text { shining, soft }\end{array}$ \\
\hline Bullera sp. 4 & 1 & $\begin{array}{l}\text { globose, napiform, } \\
(4.5-5.5) \mu \mathrm{m} \text { in diam. }\end{array}$ & maize to melon, smooth, dull-shining, soft \\
\hline Bullera sp. 5 & 1 & reniform, $(2.5-5) \times(6-11) / \mathrm{m}$ & $\begin{array}{l}\text { champagne to ivory, smooth to delicately } \\
\text { wrinkled, dull, soft }\end{array}$ \\
\hline$S$. roseus & 35 & $\begin{array}{l}\text { reniform, ovoid, } \\
(2.5-6) \times(4.5-14) / \mathrm{mm}\end{array}$ & orange red, smooth, dull-shining to dull, soft \\
\hline S. shibatanus & 4 & reniform, $(2-4.5) \times(5-8.5) / / \mathrm{m}$ & fire red to coquelicot, smooth, dull, soft \\
\hline S. subbrunneus & 1 & $\begin{array}{l}\text { reniform, } \\
(2-3) \times(6-8) / / \mathrm{m}\end{array}$ & $\begin{array}{l}\text { greyish orange to pale brown, smooth or } \\
\text { delicately wrinkled, dull, soft }\end{array}$ \\
\hline Sporobolomyces sp. & 1 & $\begin{array}{l}\text { ovoid to long ovoid, } \\
(2.5-3.5) \times(5.5-7.5), / \mathrm{m}\end{array}$ & red to night red (scarlet), smooth, dull, soft \\
\hline T. lilacina & 3 & $\begin{array}{l}\text { curved, sickle-shaped, } \\
(1.5-2.5) \times(7-16) \mu \mathrm{m}\end{array}$ & brownish orange, dry, flaky \\
\hline
\end{tabular}


NO-135, NO-147, NO-164, NO-172, NO-177.

In differing from the original description of this species (14) and that given by BARNETT et al. (13), all of the strains except one (NO-172) readily assimilated lactose as a sole carbon source. Further, latent or latent and weak growth was observed on L-sorbose, and glycerol was not assimilated by 12 out of 13 strains. Assimilation of soluble starch was also observed though sometimes it was weak. The type strain of this species (CBS 6714=JCM 2961) also assimilated soluble starch but not glycerol in our experiment.

The ballistospore-forming ability of the strains isolated in the present study varied from strain to strain: abundant in 3 strains (NO-164, NO-172, and NO177), moderate in 2 strains (NO-81 and NO-94), and poor in 3 strains (NO-7, NO44, and NO-89). The remaining 5 strains did not form ballistospores at all. However, they were assigned to this species because all of their characteristics other than ballistospore-forming ability coincided nicely with those of the ballistospore-forming strains. Strains identified with this species grow rather slowly on agar media. This may be why this species was not described until 1983 though it appears to be a very common species, at least in Japan. A high frequency of isolation $(30 \%)$ was obtained in the present study (Table 1$)$.

\section{Bullera piricola Stadelmann}

Strains: NO-9, NO-13, NO-108.

Taxonomic characteristics of the 3 strains obtained coincided nicely with the standard descriptions of this species given by RoDrigues DE Miranda (12) and BARNETT et al. (13), and those of the type strain (CBS 6754=JCM 2958).

4. Bullera oryzae Nakase et Suzuki sp. nov.

Strain: NO-65

In liquido "YM," post dies 3 ad $25^{\circ} \mathrm{C}$, cellulae subovoideae aut ovoideae, 3.5-6 $\times 5.5-8 \mu \mathrm{m}$, singulae aut binae. Pellicula formatur. In agaro "YM," post unum mensem ad $17^{\circ} \mathrm{C}$, cultura luteola, glabra, mollis, margine glabra vel undulata. Pseudomycelium non formatur. Ballistosporae rotundae et napiformes, 4.5-8 $\mu \mathrm{m}$ in diam. Fermentatio nulla. Glucosum, galactosum, saccharosum, maltosum, cellobiosum, trehalosum, lactosum, melibiosum (lente et exiguum), raffinosum, melezitosum, amylum solubile (lente), D-xylosum, L-arabinosum, Darabinosum (lente), D-ribosum (lente et exiguum), L-rhamnosum (lente), erythritolum, galactitolum, D-mannitolum, alpha-methyl-D-glucosidum, salicinum, glucono-delta-lactonum (lente), acidum 2-ketogluconicum, acidum 5-ketogluconicum, acidum DL-lacticum, acidum succinicum (lente), acidum citricum (exiguum) et inositolum assimilantur at non L-sorbosum, inulinum, ethanolum, glycerolum, ribitolum nec D-glucitolum. Kalium nitricum non assimilatur. Maxima temperatura crescentiar: $31-32^{\circ} \mathrm{C}$. Ad crescentiam thiaminum necessarium est. Proportio molaris guanini+cytosini in acido deoxyribonucleico $62.7 \mathrm{~mol} \%$. Systema coenzymatis Q principale: Q-10. Holotypus: Isolata ex Oryza sativa, Tsutsumi, Chigasaki, Kanagawa Pref., Japonia, iii. 1984, T. Nakase, JCM 5281 


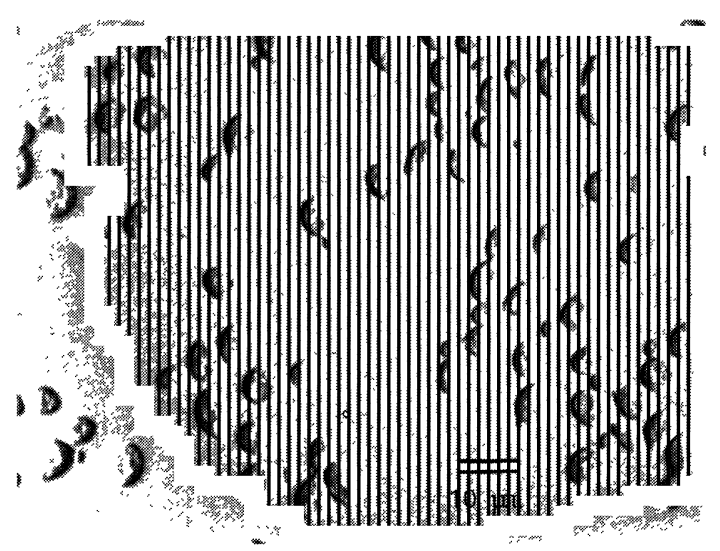

Fig. 1. Vegetative cells in the pellicle of Bullera oryzae NO-65 grown in YM broth for 3 days at $25^{\circ} \mathrm{C}$.

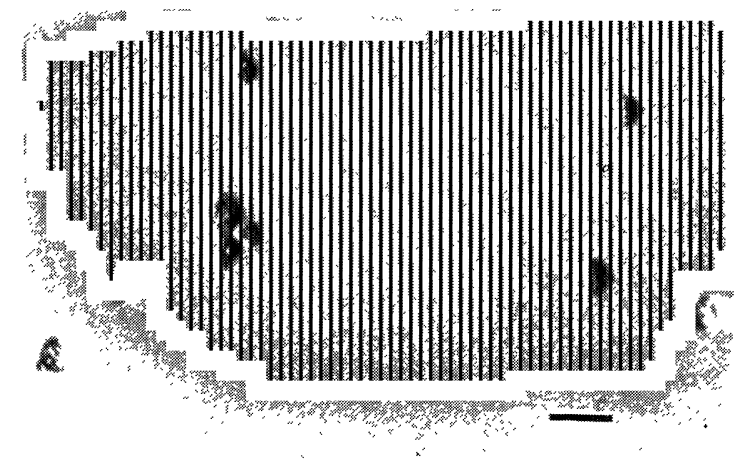

Fig. 2. Ballistospores of Bullera oryzae NO-65 grown on corn meal agar for 7 days at $17-20^{\circ} \mathrm{C}$. Ballistospores were collected over night on glass slides.

(originaliter ut NO-65); in collectione quam 'Japan Collection of Microorganisms,' Wako sustentat.

Growth in YM broth: After 3 days at $25^{\circ} \mathrm{C}$, cells are short oval to oval, (3.5-6) $\times(5.5-8) \mu \mathrm{m}$, single or in pairs (Fig. 1). A sediment and a thin, smooth and creeping pellicle are formed. After one month at $17^{\circ} \mathrm{C}$, the pellicle is thin and delicately wrinkled.

Growth on YM agar: After one month at $17^{\circ} \mathrm{C}$, the colony is light yellow to apricot, smooth, dull, soft and has entire to undulate margin.

Dalmau plate culture on corn meal agar: No pseudomycelium is formed.

Formation of ballistospores: Ballistospores are abundantly formed on YM agar and corn meal agar. They are almost round or napiform (Fig. 2), (4.5-8) $\mu \mathrm{m}$ in diam. 
Fermentation: Not observed.

Assimilation of carbon compounds:

$\begin{array}{ll}\text { Glucose } & + \\ \text { Galactose } & + \\ \text { L-Sorbose } & - \\ \text { Sucrose } & + \\ \text { Maltose } & + \\ \text { Cellobiose } & + \\ \text { Trehalose } & + \\ \text { Lactose } & + \\ \text { Melibiose } & + \text { (latent and weak) } \\ \text { Raffinose } & + \\ \text { Melezitose } & + \\ \text { Inulin } & - \\ \text { Soluble starch } & + \text { (slow) } \\ \text { D-Xylose } & + \\ \text { L-Arabinose } & + \\ \text { D-Arabinose } & + \text { (latent) } \\ \text { D-Ribose } & + \text { (latent and weak) }\end{array}$

$\begin{array}{ll}\text { L-Rhamnose } & + \text { (latent) } \\ \text { Ethanol } & - \\ \text { Glycerol } & - \\ \text { Erythritol } & + \\ \text { Ribitol } & - \\ \text { Galactitol } & + \\ \text { D-Mannitol } & + \\ \text { D-Glucitol } & - \\ \alpha \text {-Methyl-D-glucoside } & + \\ \text { Salicin } & + \\ \text { Glucono- } \delta \text {-lactone } & + \text { (latent) } \\ \text { 2-Ketogluconic acid } & + \\ \text { 5-Ketogluconic acid } & + \\ \text { DL-Lactic acid } & + \\ \text { Succinic acid } & + \\ \text { Citric acid } & + \text { (weak) } \\ \text { Inositol } & + \\ \end{array}$

Assimilation of nitrogen compounds:

Ammonium sulfate $+\quad$ Ethylamine hydrochloride

Potassium nitrate -

L-Lysine

+
+
+ (latent)

Sodium nitrite $+\quad$ Cadaverinedihydrochloride

Maximum growth temperature: $31-32^{\circ} \mathrm{C}$.

Vitamin required: Thiamine.

Production of starch-like substances: Positive.

Growth on $50 \%$ glucose agar: Negative.

Urease: Positive.

Liquefaction of gelatin: Negative.

Hydrolysis of fat: Negative.

$\mathrm{G}+\mathrm{C}$ content of nuclear DNA: $62.7 \mathrm{~mol} \%$.

Major ubiquinone: Q-10.

Type: NO-65 isolated from Oryza sativa $\mathrm{L}$. is the type of this species. It was deposited with the Japan Collection of Microorganisms, Wako, Saitama, as JCM 5281, and the Institute for Fermentation, Osaka, as IFO 10166.

This yeast forms rotationally symmetrical ballistospores, and pale colored colonies, and is considered one of the typical species of the genus Bullera. By taxonomic criteria commonly employed in yeast classification, this yeast resembles $B$. alba in several respects. It is apparent, however, that it is distinct from $B$. alba because the $\mathrm{G}+\mathrm{C}$ content in the DNA of this species is $62.7 \%$ (Table 5 ). This is much higher than that $(54.4 \%)$ of $B$. alba reported previously (15). These two species can be easily distinguished from each other in the following charac- 
Table 3. Physiological and biochemical characteristics of ballistospore-forming yeasts

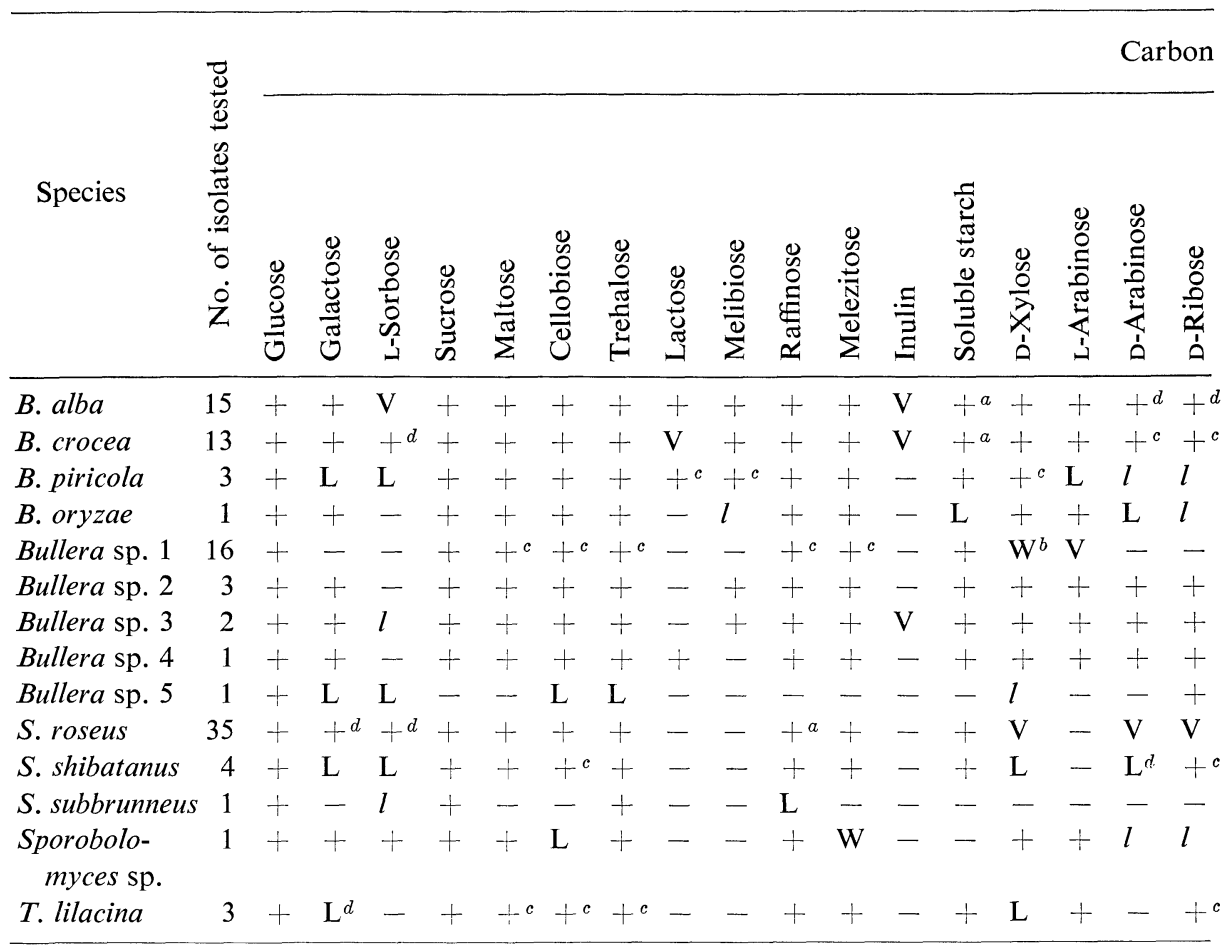

+ : Positive, - : Negative, L: Latent, W: Weak, $l$ : Latent and weak, V: Variable.

a May be weak.

$b$ May be negative.

teristics: $B$. oryzae assimilates nitrite but not lactose and D-glucitol, while $B$. alba does not assimilate nitrite and assimilates lactose and D-glucitol (Table 3).

5. Bullera sp. 1.

Strains: NO-6, NO-20, NO-59, NO-67, NO-79, NO-93, NO-97, NO-102, NO-104, NO-111, NO-112, NO-116, NO-120, NO-121, NO-123, NO-168.

The sixteen strains assigned to this species formed large ballistospores. Some of them appeared to be bilaterally symmetrical. Others are rotationally symmetrical and resemble $B$. piricola in this respect. However, we could not assign these isolates to $B$. piricola because they were clearly distinguishable from $B$. piricola in their biochemical characteristics. Namely, strains assigned to $B$. piricola including the type strain (CBS 6754 = JCM 2958) assimilated galactose, L-sorbose, lactose, melibiose, and inositol, while strains assigned to this species assimilated none of these carbon compounds (Table 3). However, we hesitated to describe this yeast as a new species because similar values were found in the $\mathrm{G}+\mathrm{C}$ content in DNAs extracted from this yeast and B. piricola (Table 5). Further precise comparative studies of these two yeasts such as DNA-DNA homology 
isolated from Oryza sativa L. (1). Assimilation of carbon and nitrogen compounds.

\begin{tabular}{|c|c|c|c|c|c|c|c|c|c|c|c|c|c|c|c|c|c|c|c|c|c|}
\hline \multicolumn{17}{|c|}{ compounds } & \multicolumn{5}{|c|}{$\begin{array}{l}\text { Nitrogen } \\
\text { compounds }\end{array}$} \\
\hline 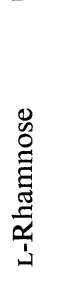 & 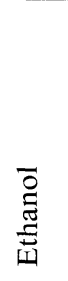 & $\begin{array}{l}\overline{0} \\
\frac{0}{0} \\
\frac{2}{0}\end{array}$ & 预 & $\overline{0}$ & $\begin{array}{l}\overline{0} \\
\stackrel{0}{0} \\
\frac{\tilde{J}}{\pi} \\
0 \\
0\end{array}$ & 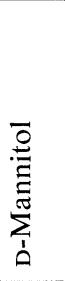 & $\begin{array}{l}\overline{0} \\
\stackrel{0}{0} \\
\frac{0}{0} \\
\dot{0} \\
\dot{0}\end{array}$ & 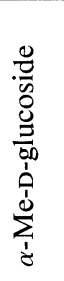 & 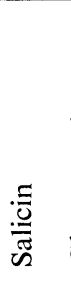 & 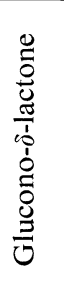 & 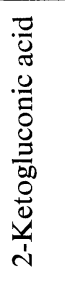 & 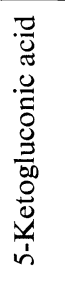 & 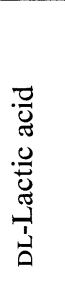 & 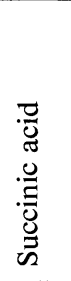 & 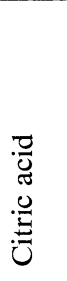 & $\begin{array}{l}\overline{0} \\
\stackrel{0}{0} \\
0 \\
g\end{array}$ & 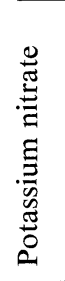 & 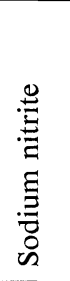 & 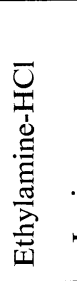 & 壳 & 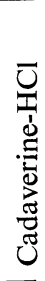 \\
\hline+ & - & - & - & $+^{d}$ & $+^{d}$ & + & + & + & $+^{a}$ & $+^{d}$ & + & + & - & $+^{d}$ & $+^{d}$ & + & - & - & + & 1 & \\
\hline$+^{c}$ & - & - & $l$ & - & + & $+^{a}$ & - & L & $+d$ & + & + & + & $l^{b}$ & $+^{d}$ & $+^{a}$ & $-d$ & - & $-c$ & + & 1 & \\
\hline - & $\mathrm{L}^{d}$ & $l$ & - & $l$ & $l$ & $\mathrm{~L}$ & $\mathrm{~L}$ & $l$ & $+^{c}$ & $+^{c}$ & + & $+^{c}$ & - & $\mathrm{L}$ & $\mathrm{L}$ & + & + & + & - & 1 & \\
\hline 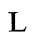 & - & - & + & - & + & + & - & + & + & $\mathrm{L}$ & + & + & + & + & $\mathrm{W}$ & + & - & + & + & + & \\
\hline- & $l^{b}$ & $\mathrm{~W}^{b}$ & - & $\mathrm{W}^{b}$ & - & $+^{c}$ & $\mathrm{~V}$ & - & $+^{d}$ & $+^{d}$ & $+^{c}$ & $\mathrm{~V}$ & - & $+^{d}$ & $\mathbf{L}^{d}$ & - & + & + & - & - & \\
\hline+ & - & - & - & - & $+^{c}$ & L & + & $+c$ & $+^{c}$ & + & + & + & $\mathrm{L}^{d}$ & + & $l^{b}$ & + & - & - & - & + & - \\
\hline+ & + & + & + & $+^{a}$ & + & + & + & + & + & + & + & + & $l^{b}$ & + & $+^{a}$ & + & - & - & + & + & \\
\hline+ & $l$ & $l$ & - & + & + & + & + & $l$ & + & + & + & + & - & + & + & + & - & - & + & + & \\
\hline- & + & $\mathrm{L}$ & - & $\mathrm{L}$ & - & $\mathrm{L}$ & + & - & - & + & + & + & - & + & + & - & - & - & & $\mathrm{L}$ & \\
\hline- & $+^{c}$ & $+^{d}$ & - & V & - & $+^{c}$ & $+^{c}$ & $+^{c}$ & + & + & - & - & V & $+^{a}$ & V & - & + & + & $+^{d}$ & 1 & \\
\hline- & $\mathrm{L}$ & $\mathrm{L}$ & - & + & - & + & + & $+^{c}$ & + & + & - & - & - & $+^{a}$ & $+^{a}$ & - & - & - & + & 1 & \\
\hline- & - & $\mathrm{L}$ & - & $\mathrm{L}$ & - & + & $\mathrm{L}$ & - & - & W & - & - & W & W & W & - & + & - & - & - & \\
\hline- & - & + & - & W & - & + & + & $\mathrm{L}$ & - & - & - & W & $l$ & + & $\mathrm{W}$ & - & - & - & - & - & - \\
\hline- & - & $\mathrm{L}$ & + & - & - & + & $+^{c}$ & - & - & - & - & - & $\mathrm{L}$ & + & + & - & + & + & - & 1 & \\
\hline
\end{tabular}

are required to determine whether it is a new species.

6. Bullera sp. 2.

Strains: NO-10, NO-11, NO-43.

Strains assigned to this species formed uniquely-shaped ballistospores which often appeared to be rotationally symmetrical but in fact they were bilaterally symmetrical and chestnut-shaped with a hilum on the deflected position. This species formed cream colored colonies, assimilated 2-keto- and 5-ketogluconic acid, and produced starch-like substances. Therefore, we placed it in the genus Bullera. The carbon assimilation pattern of this species did not coincide with any hitherto described species of Bullera and Sporobolomyces. We think this is a new species of Bullera. At present, however, we do not describe it as a new species because several ballistospore-forming yeasts exhibiting physiological and biochemical characteristics similar to the present isolates were obtained from several kinds of plants in Japan and in Canada. These isolates formed ballistospores of various shapes. Further comparative taxonomic studies among the 
Table 4. Physiological and biochemical characteristics of ballisotospore-forming yeasts isolated from Oryza sativa L. (2).

\begin{tabular}{|c|c|c|c|c|c|c|c|c|c|c|}
\hline Species & $\begin{array}{l}\text { No. of } \\
\text { strains } \\
\text { tested }\end{array}$ & $\begin{array}{l}\text { Maximum } \\
\text { growth } \\
\text { tempera- } \\
\text { ture } \\
\left({ }^{\circ} \mathrm{C}\right)\end{array}$ & $\begin{array}{l}\text { Vitamins } \\
\text { required }^{a}\end{array}$ & $\begin{array}{l}\text { Production, } \\
\text { of "starch" }\end{array}$ & $\begin{array}{l}\text { Production } \\
\text { of acids }\end{array}$ & $\begin{array}{c}\text { Growth } \\
\text { on } 50 \% \\
\text { glucose } \\
\text { agar }\end{array}$ & Urease & $\begin{array}{l}\text { Lique- } \\
\text { faction } \\
\text { of } \\
\text { gelatin }\end{array}$ & $\begin{array}{l}\text { Split of } \\
\text { fat }\end{array}$ & $\begin{array}{l}\text { Alcoholic } \\
\text { fermen- } \\
\text { tation }\end{array}$ \\
\hline B. alba & 15 & $27-31$ & $\mathrm{~T}$ & + & - & 1 & + & 1 & 1 & - \\
\hline B. crocea & 13 & $26-31$ & $\mathrm{~T}$ & $-b$ & - & 1 & + & 1 & 1 & - \\
\hline B. piricola & 3 & $23-24$ & $\mathrm{~B}, \mathrm{~T}$ & $-c$ & - & 1 & + & 1 & 1 & - \\
\hline B. oryzae & 1 & $31-32$ & $\mathrm{~T}$ & $+^{b}$ & - & - & + & - & - & - \\
\hline Bullera sp. 1 & 16 & $23-24$ & $\mathrm{~B}, \mathrm{~T}$ & - & - & - & + & $\mathrm{LW}^{d}$ & - & - \\
\hline Bullera sp. 2 & 3 & $29-30$ & $\mathrm{~T}$ & + & - & - & + & - & - & - \\
\hline Bullera sp. 3 & 2 & $29-31$ & $\mathrm{~T}$ & - & - & - & + & - & - & - \\
\hline Bullera sp. 4 & 1 & $29-30$ & $\mathrm{~T}$ & - & - & - & + & - & - & - \\
\hline Bullera sp. 5 & 1 & $25-26$ & $\mathrm{~T}$ & - & - & - & + & - & - & - \\
\hline S. roseus & 35 & $27-34$ & Nil & - & - & 1 & + & 1 & 1 & - \\
\hline S. shibatanus & 4 & $30-32$ & Nil & - & - & 1 & + & 1 & 1 & - \\
\hline S. subbrunneus & 1 & $29-30$ & PABA, T & - & - & - & + & - & - & - \\
\hline Sporobolomyces sp. & 1 & $29-30$ & PABA, T & - & - & - & + & - & - & - \\
\hline T. lilacina & 3 & $29-31$ & $\mathrm{~T}$ & - & - & 1 & + & 1 & 1 & - \\
\hline
\end{tabular}

$a$ B: Biotin, T: Thiamine, PABA: $p$-Aminobenzoic acid, Nil: Vitamins not required.

$b$ Very weakly positive in some strains.

c Weakly positive or negative.

$d$ LW: Latent"and"weak. 
Table 5. DNA base composition of ballistospore-forming yeasts isolated from Oryza sativa $\mathrm{L}$. and related species.

\begin{tabular}{|c|c|c|}
\hline Species & Strain & $\mathrm{mol} \% \mathrm{G}+\mathrm{C}^{a}$ \\
\hline B. oryzae & NO-65 & 62.7 \\
\hline Bullera sp. 1 & NO-6 & 48.8 \\
\hline Bullera sp. 2 & NO-11 & 56.5 \\
\hline Bullera sp. 3 & NO-92 & 54.3 \\
\hline Bullera sp. 4 & NO-165 & 53.6 \\
\hline Bullera sp. 5 & NO-157 & 57.8 \\
\hline S. subbrunneus & NO-14 & 68.0 \\
\hline B. piricola & JCM 2958 & 50.8 \\
\hline C. parapsilosis & $\mathrm{JCM} 1785^{b}$ & 40.8 \\
\hline
\end{tabular}

a $\mathrm{Mol} \% \mathrm{G}+\mathrm{C}$ was calculated from $\mathrm{Tm}$. Three to five $\mathrm{Tm}$ determinations were done on each DNA sample.

$b$ Type strain of this species.

present isolates and isolates obtained from other plants are required before we describe this yeast as a new species.

7. Bullera sp. 3.

Strains: NO-66, NO-92.

Two strains assigned to this species formed rotationally symmetrical ballistospores which are almost round and napiform. It resembles $B$. alba and B. oryzae in several respects. The $\mathrm{G}+\mathrm{C}$ content of the DNA is $54.3 \%$ (Table 5) which is similar to $B$. alba (15). Therefore, further precise comparative studies of these two species are required before we determine whether this is a new species. By the taxonomic criteria commonly employed, this species can be distinguished from $B$. alba by its rapid assimilation of ethanol, glycerol, erythritol, and by the lack of assimilation of lactose.

8. Bullera sp. 4.

Strain: NO-165.

This yeast formed rotationally symmetrical ballistospores which appeared to be almost round and napiform. The physiological and biochemical characteristics resemble $B$. alba. However, it could be distinguished from $B$. alba by the lack of assimilation of melibiose and the lack of production of starch-like substances. The $\mathrm{G}+\mathrm{C}$ content of its DNA was $53.6 \%$ (Table 5) which was close to that of $B$. alba (15). Therefore, a precise comparative study with $B$. alba is required before we determine the taxonomic position of this yeast.

9. Bullera sp. 5.

Strain: NO-157.

This yeast formed pale colored colonies and bilaterally symmetrical ballistospores. These characteristics resemble $B$. singularis. However, this yeast differed from $B$. singularis in the assimilation of lactose, L-arabinose, D-arabinose, salicin, and DL-lactic acid (Table 3), and in the pattern of vitamin requirement (Table 4). 
Table 6. Ubiquinone system of ballistospore-forming yeasts isolated from Oryza sativa $\mathbf{L}$.

\begin{tabular}{llccc}
\hline \multirow{2}{*}{ Species } & \multirow{2}{*}{ Strain } & \multicolumn{3}{c}{ Molar ratio of ubiquinone isoprenologues (\%) } \\
\cline { 3 - 5 } & & Q-8 & Q-9 & Q-10 \\
\hline B. oryzae & NO-65 & $-a$ & 4.6 & 95.4 \\
Bullera sp. 1 & NO-6 & - & 7.1 & 92.9 \\
$\quad$ "I & NO-102 & - & 8.3 & 91.7 \\
Bullera sp. 2 & NO-10 & - & 2.4 & 97.6 \\
Bullera sp. 3 & NO-92 & - & 2.1 & 97.9 \\
Bullera sp. 4 & NO-165 & - & 11.0 & 89.0 \\
Bullera sp. 5 & NO-157 & 7.7 & 92.3 & - \\
S. subbrunneus & NO-14 & - & 7.8 & 92.2 \\
Sporobolomyces sp. & NO-12 & - & 4.9 & 95.1 \\
\hline
\end{tabular}

a - : Not detected.

The major ubiquinone of this yeast was Q-9 (Table 6). According to YAMADA and Kondo (16) and YAMADA et al. (17), the coenzyme Q (ubiquinone) systems of the species of the genera Bullera and Sporobolomyces are Q-10. Since ubiquinone is considered to be a valuable generic characteristic, this species might be included in a genus to be newly established. The colorless colonies of this yeast and its ability to assimilate 2-keto- and 5-ketogluconic acid coincided with the characteristics of typical species of Bullera. But the shape of the ballistospores was similar to typical species of Sporobolomyces. Further detailed study including $B$. singularis is required to determine the taxonomic position of this yeast.

10. Sporobolomyces roseus Kluyver et van Niel

Strains: NO-3, NO-4, NO-5, NO-8, NO-16, NO-22, NO-25, NO-26, NO-29, NO-31, NO-45, NO-46, NO-47, NO-51, NO-57, NO-64, NO-68, NO-71, NO-78, NO-80, NO-91, NO-95, NO-99, NO-100, NO-106, NO-107, NO-113, NO-118, NO-126, NO-145, NO-151, NO-159, NO-163, NO-166, NO-171.

The taxonomic characteristics of these 35 isolates assigned to S. roseus coincided with descriptions of this species given by Phaff (18), and Fell and Tallman (6), with several minor exceptions.

11. Sporobolomyces shibatanus (Okunuki) Verona et Ciferri

Strains: NO-63, NO-74, NO-149, NO-174.

The taxonomic characteristics of these 4 strains coincided nicely with the descriptions of Sporidiobolus pararoseus (teleomorph of $S$. shibatanus) given by Fell and Tallman (6), and Barnett et al. (13) except for teliospore formation. Mating experiments were not carried out in the present study.

12. Sporobolomyces subbrunneus Nakase et Suzuki sp. nov.

Strain: NO-14

In liquido "YM," post dies 3 ad $25^{\circ} \mathrm{C}$, cellulae longi-ellipsoidales, 1.5-2.7 $\times$ 6-10 $\mu \mathrm{m}$, singulae aut binae. Pellicula non formatur. In agaro "YM," post unum mensem ad $17^{\circ} \mathrm{C}$, cultura subbrunnea, glabra aut rugulosa, mollis, margine 


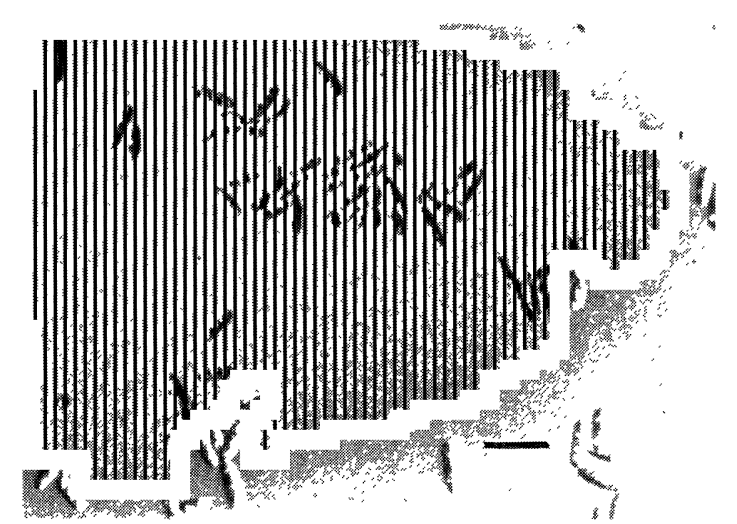

Fig. 3. Vegetative cells of Sporobolomyces subbrunneus NO-14 grown in YM broth for 3 days at $25^{\circ} \mathrm{C}$.

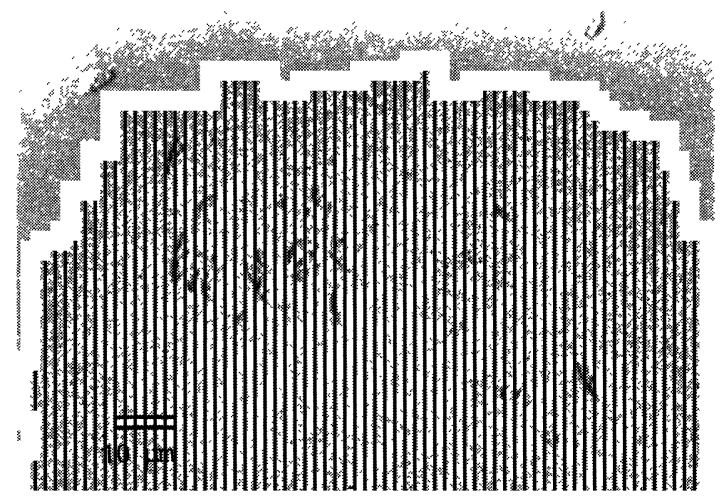

Fig. 4. Ballistospores of Sporobolomyces subbrunneus NO-14 grown on corn meal agar for 14 days at $17-20^{\circ} \mathrm{C}$. Ballistospores were collected over night on glass slides.

glabra. Pseudomycelium primitivum formatur. Ballistosporae reniformes, $2-3 \times$ 6-8 $\mu \mathrm{m}$. Fermentatio nulla. Glucosum, L-sorbosum (lente et exiguum), saccharosum, trehalosum, raffinosum (lente), glycerolum (lente), ribitolum (lente), D-mannitolum, D-glucitolum (lente), glucono-delta-lactonum (exiguum), acidum DL-lacticum (exiguum), acidum succinicum (exiguum) et acidum citricum (exiguum) assimilantur at non galactosum, maltosum, cellobiosum, lactosum, melibiosum, melezitosum, inulinum, amylum solubile, D-xylosum, L-arabinosum, D-arabinosum, D-ribosum, L-rhamnosum, ethanolum, erythritolum, galactitolum, alpha-methyl-D-glucosidum, salicinum, acidum 2-ketogluconicum, acidum 5ketogluconicum nec inositolum. Kalium nitricum assimilatur. Maxima temperatura crescentiar: $29-30^{\circ} \mathrm{C}$. Ad crescentiam acidum $p$-aminobenzonicum et thiaminium necessarium sunt. Proportio molaris guanini+cytosini in acido deoxyribonucleico $68.0 \mathrm{~mol} \%$. Systema coenzymatis Q principale: Q-10. Holo- 
Table 7. Distribution of ballistospore-forming

\begin{tabular}{|c|c|c|c|c|}
\hline \multirow{3}{*}{ Species } & \multicolumn{3}{|c|}{ Akabane district } & Tsutsumi district \\
\hline & Feb. 5 & \multicolumn{2}{|r|}{ Feb. 12} & Mar. 4 \\
\hline & $\begin{array}{lll}1 & 2 & 3\end{array}$ & $\begin{array}{lll}4 & 5 & 6\end{array}$ & $\begin{array}{lllllll}7 & 8 & 9 & 10 & 11 & 12 & 13\end{array}$ & $\begin{array}{llllllll}14 & 15 & 16 & 17 & 18 & 19 & 20 & 21\end{array}$ \\
\hline
\end{tabular}

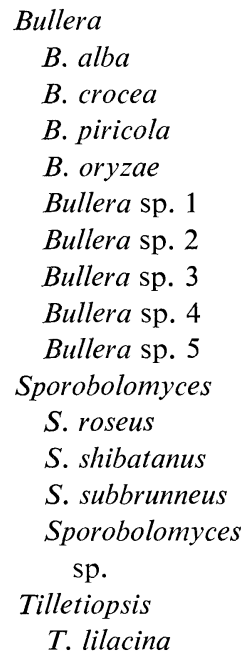

typus: Isolata ex Oxyza sativa, Akabane, Chigasaki, Kanagawa Pref., Japonia, ii. 1984, T. Nakase, JCM 5278 (originaliter ut NO-14); in collectione quam 'Japan Collection of Microorganisms,' Wako sustentat.

Growth in YM broth: After 3 days at $25^{\circ} \mathrm{C}$, cells are long ellipsoidal, (1.5$2.7) \times(6-10) \mu \mathrm{m}$, single or in pairs (Fig. 3). A sediment and a trace of ring are formed. After one month at $17^{\circ} \mathrm{C}$, a sediment, a ring and a few islets are present.

Growth on YM agar: After one month at $17^{\circ} \mathrm{C}$, the colony is greyish orange to pale brown, smooth or delicately wrinkled, dull, soft, and has an entire margin.

Dalmau plate culture on corn meal agar: A primitive pseudomycelium is formed.

Formation of ballistospores: Ballistospores are formed on corn meal agar. They are bilaterally symmetrical, reinform, (2-3) $\times(6-8) \mu \mathrm{m}$ (Fig. 4).

Fermentation: Not observed.

Assimilation of carbon compounds:

$\begin{array}{llll}\text { Glucose } & + & \text { L-Rhamnose } & - \\ \text { Galactose } & - & \text { Ethanol } & - \\ \text { L-Sorbose } & + \text { (latent and weak) } & \text { Glycerol } & + \text { (slow) } \\ \text { Sucrose } & + & \text { Erythritol } & - \\ \text { Maltose } & - & \text { Ribitol } & + \text { (latent) }\end{array}$


yeasts in Oryza sativa $\mathbf{L}$.

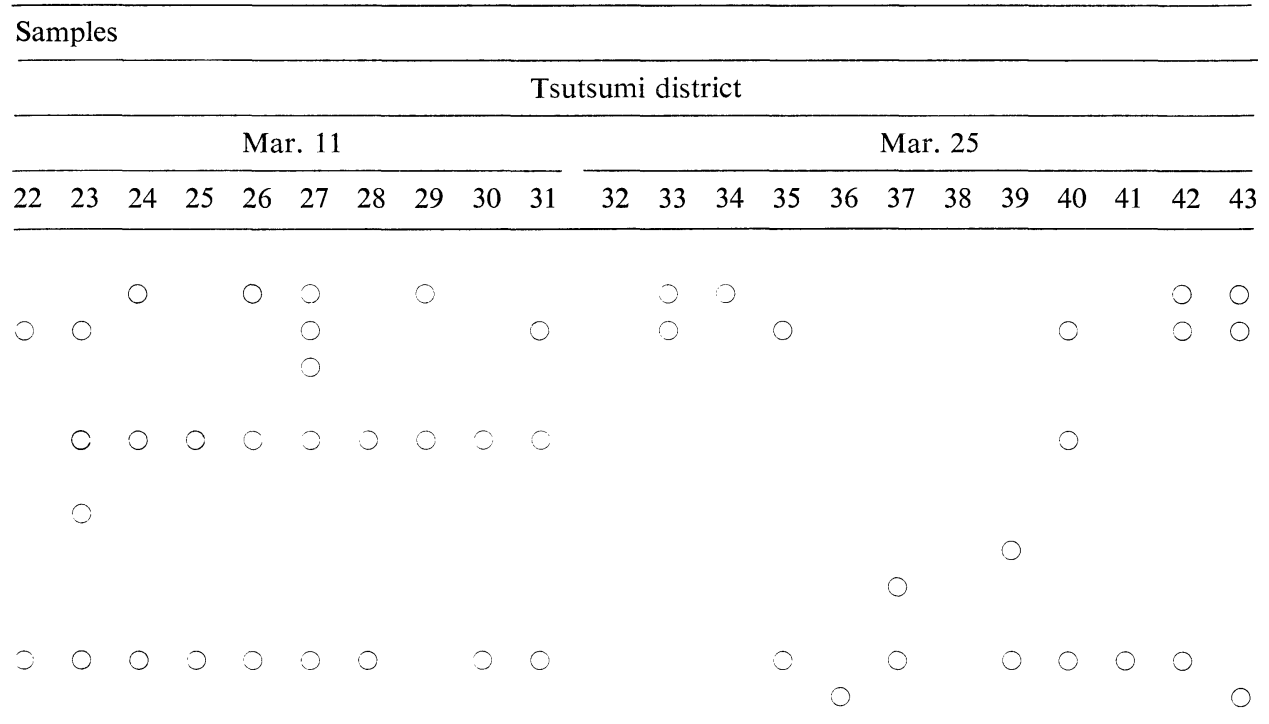

$\begin{array}{ll}\text { Cellobiose } & - \\ \text { Trehalose } & + \\ \text { Lactose } & - \\ \text { Melibiose } & - \\ \text { Raffinose } & + \text { (latent) } \\ \text { Melezitose } & - \\ \text { Inulin } & - \\ \text { Soluble starch } & - \\ \text { D-Xylose } & - \\ \text { L-Arabinose } & - \\ \text { D-Arabinose } & - \\ \text { D-Ribose } & -\end{array}$

Galactitol

D-Mannitol

$-$

D-Glucitol

$\alpha$-Methyl-D-glucoside

+ (latent)

Salicin

Glucono- $\delta$-lactone

2-Ketogluconic acid

5-Ketogluconic acid

DL-Lactic acid

Succinic acid

Citric acid

Inositol

-

$-$

+ (weak)

$-$

$-$

+ (weak)

+ (weak)

+ (weak)
Assimilation of nitrogen compounds:

Ammonium sulfate +

Potassium nitrate +

Sodium nitrite _-
Ethylamine hydrochloride

Cadaverinedihydrochloride -
L-Lysine

Maximum growth temperature: $29-30^{\circ} \mathrm{C}$.

Vitamins required: $p$-Aminobenzoic acid and thiamine.

Production of starch-like substances: Negative. 
Growth on $50 \%$ glucose agar: Negative.

Urease: Positive.

Liquefaction of gelatin: Negative.

Splitting of fat: Negative.

$\mathrm{G}+\mathrm{C}$ content of nuclear DNA: $68.0 \mathrm{~mol} \%$.

Major ubiquinone: Q-10.

Type: Strain NO-14 isolated from Oryza sativa L. is the type of this species. It was deposited with the Japan Collection of Microorganisms, RIKEN, Wako, Saitama Pref. as JCM 5278, and the Institute for Fermentation, Osaka as IFO 10168.

This yeast formed bilaterally symmetrical ballistospores and formed greyish orange to pale brown colonies. In spite of the poor pigmentation of its colonies, we placed this yeast in the genus Sporobolomyces because it could not assimilate 2-keto- and 5-ketogluconic acid. As reported by Stadelmann (19), ability to assimilate these two compounds is found in typical species of Bullera but not in typical species of Sporobolomyces. This yeast required $p$-aminobenzoic acid for growth (Table 4) and resembled $S$. gracilis in this respect. However, clear differences were found between the two species in the assimilation of sucrose, raffinose, salicin, nitrate and nitrite, and maximum growth temperature (Tables 3 and 4). Further, these two yeasts can be easily distinguished by the pigmentation of colonies: pale in $S$. subbrunneus and deep red (scarlet) in $S$. gracilis.

13. Sporobolomyces sp.

Strain: NO-12.

The pigmentation of the colonies of this species was like that of typical Sporobolomyces. However, rotationally symmetrical ballistospores were formed in this yeast. Further, it assimilated 5-ketogluconic acid though weak. These characteristics are not common in the ballistospore-forming yeasts. We tentatively place this yeast in the genus Sporobolomyces because its overall characteristics resemble Sporobolomyces more than Bullera. The pattern of the carbon assimilation of this yeast did not concide with any known species of ballistospore-forming yeasts.

\section{Tilletiopsis lilacina Tubaki}

Strains: NO-2, NO-42, NO-69.

The morphological, physiological, and biochemical characteristics of these isolates coincided nicely with those reported by TUBAKI (20) and YAMAZAKI et al. (21).

Distribution of ballistospore-forming yeasts on the surface of Oryza sativa L.

By the method employed in the present study, yeasts were isolated from all of the 43 samples of dead leaves and stems of Oryza sativa L. Out of 175 strains obtained, 94 formed ballistospores. The remaining 81 strains did not form ballistospores on any of the media tested. Five strains out of 81 of non-ballistospore- 
forming yeasts were assigned to $B$. crocea since taxonomic characteristics other than ballistospore formation coincided nicely with this species. The remaining 76 strains were regarded as non-ballistosporous yeasts though some of them might form ballistospores under certain conditions.

Ballistospore-forming yeasts were isolated from 37 samples and the frequency of isolation was $86 \%$ (Table 1). Sporobolomyces roseus is the most common species found in Oryza sativa L. and the frequency of isolation of this species was very high (72\%). Bullera sp. 1, B. crocea, and B. alba were also isolated at the high frequency of $35 \%, 30 \%$, and $28 \%$, respectively (Table 1 ). The frequency of isolation of the remaining 10 species of Bullera, Sporobolomyces, and Tilletiopsis were below $9 \%$ (Table 1 ).

An average of 2.4 species were isolated from each of the samples from which ballistospore-forming yeasts were isolated. More than one species and up to 6 ballistospore-forming yeasts were found in 27 samples (Table 7). No clear difference was found in the kinds of species isolated from the Akabane and Tsutsumi districts (Table 7). Precise distinctions between the two districts could not be made in this respect since the dates of collection at the two places were not the same. Out of 14 species isolated and identified in the present study, eight were considered to represent hitherto undescribed species. It is assumed that a number of undescribed ballistospore-forming yeast species are living on the surface of other plants since such a large number of undescribed species were found on this one kind of plant. We believe that trials to isolate new kinds of yeasts from nature contribute much to the progress of the taxonomy of ballistospore-forming yeasts, in addition to the approaches based on the improved chemotaxonomic methods and refined techniques for the investigation of the fine structure of yeast cells.

We thank Dr. K. Tubaki, Institute of Biological Sciences, University of Tsukuba, Ibaraki, and Dr. L. Rodrigues de Miranda, Centraalbureau voor Schimmelcultures, Delft, The Netherlands, for their invaluable suggestions in this study. We also thank Dr. J. Sugiyama, The Institute of Applied Microbiology, University of Tokyo, Tokyo, for his kind help in the preparation of Latin diagnoses.

\section{REFERENCES}

1) K. Okunuki, Jpn. J. Bot., 5, 285 (1931).

2) I. YAMASAKI and H. FujII, Nippon Nogeikagaku Kaishi, 24, 11 (1950).

3) K. Tubaki, Nagaoa, 3, 12 (1953).

4) K. Tubaki, Bot. Mag. Tokyo, 71, 131 (1958).

5) H. Irzuka and S. Goto, J. Gen. Appl. Microbiol., 11, 331 (1965).

6) J. W. Fell and A. S. Tallman, In The Yeasts: A Taxonomic Study, 3rd ed., ed. by N. J. W. Kreger-van RiJ, Elsevier Science Publ., Amsterdam (1984), p. 532, 911.

7) H. G. DerX, Ann. Mycol., 28, 1 (1930).

8) J. P. VAN Der Walt, In The Yeasts: A Taxonomic Study, 2nd ed., by J. Lodder, NorthHolland Publ., Amsterdam (1970), p. 34.

9) J. P. van Der Walt and D. Yarrow, In The Yeasts: A Taxonomic Study, 3rd ed., ed. by 
N. J. W. Kreger-van Rij, Elsevier Science Publ., Amsterdam (1984), p. 45.

10) K. Komagata and T. NaKASE, Shokuhin Eiseigaku Zasshi, 8, 53 (1967).

11) T. Nakase and M. Suzuki, J. Gen. Appl. Microbiol., 31, 49 (1985).

12) L. Rodrigues de Miranda, In The Yeasts: A Taxonomic Study, 3rd ed., ed. by N. J. W. Kreger-VAN RiJ, Elsevier Science Publ., Amsterdam (1984), p. 577.

13) J. A. Barnett, R. W. Payne, and D. Yarrow, Yeasts: Characteristics and Identification, Cambridge University Press, Cambridge (1983).

14) R. W. Buhagiar, D. Yarrow, and J. A. Barnet1', J. Gen. Microbiol., 129, 3149 (1983).

15) T. Nakase and K. Komagata, J. Gen. Appl. Microbiol., 17, 363 (1971).

16) Y. Yamada and K. Kondo, J. Gen. Appl. Microbiol., 19, 59 (1973).

17) Y. Yamada, T. Ohishi, and K. Kondo, J. Gen. Appl. Microbiol., 29, 51 (1983).

18) H. J. Phaff, In The Yeasts: A Taxonomic Study, 2nd ed., ed. by J. Looder, North-Holland Publ., Amsterdam (1970), p. 831.

19) F. Stadelmann, Antonie van Leeuwenhoek: J. Microbiol. Serol., 41, 575 (1975).

20) K. Tubaki, Nagaoa, 1, 26 (1952).

21) M. Yamazaki, S. Goto, and K. Komagata, Trans. Mycol. Soc. Jpn., 26, 13 (1985). 